\title{
Az IMEA ADR III kritikus fúziós frekvenciavizsgáló eszközzel végzett mérések reprodukálhatóságának vizsgálata
}

\author{
Angeli Orsolya oh. ${ }^{1}$ - Veres Dániel Sándor dr. ${ }^{2}$ \\ Nagy Zoltán Zsolt dr. ${ }^{3}$ - Schneider Miklós dr. ${ }^{3}$ \\ ${ }^{1}$ Semmelweis Egyetem, Általános Orvostudományi Kar, Budapest \\ Semmelweis Egyetem, Általános Orvostudományi Kar, \\ ${ }^{2}$ Biofizikai és Sugárbiológiai Intézet, ${ }^{3}$ Szemészeti Klinika, Budapest
}

\begin{abstract}
Bevezetés: A centrális kritikus fúziós frekvencia (CFF) mérése a szemészetben gyakran alkalmazott vizsgálat, segítséget adhat több szemészeti, neurológiai, belgyógyászati betegség diagnosztizálásában, illetve meglévő betegségek progreszsziójának követésében. Célkitüzés: A szerzők az IMEA ADR III digitális CFF-mérő készüléket tesztelték 30 fiatal, egészséges, magyar személyen. Módszer: Általános szemészeti vizsgálatot követően, a múszer által kibocsátott négyféle fénnyel végeztek méréseket, minden színnel ötször egymás után, két különböző napon, három különböző időpontban, standardizált körülmények mellett. A statisztikai elemzés során az intrasession-, intersession- és intervisit-variabilitást, az egyes színek közötti különbségeket és egyes befolyásoló faktorok hatásait vizsgálták. Eredmények: Az egyes mérési sorozatok között sem középértékben, sem a szórásokban nem találtak különbséget. A vörös színnel végzett vizsgálat küszöbérték-eredményei statisztikailag alacsonyabbak voltak a többinél, illetve a kék szín küszöbértékei alacsonyabbak voltak a zöldnél. A nemre, életkorra, íriszszínre és dohányzásra vonatkozóan nem találtak különbségeket a küszöbértékekben. Következtetések: A műszer egészséges populáción, egymástól független időpontokban, megbízhatóan, pontosan mér, az eredmények jól reprodukálhatóak. Orv. Hetil., 2016, 157(27), 1079-1086.
\end{abstract}

Kulcsszavak: kritikus fúziós frekvencia, CFF, reprodukálhatóság

\section{Reproducibility of measurements using the IMEA ADR III critical flicker-fusion frequency measuring device}

Introduction: Measurement of central critical flicker-fusion frequency is a common screening test for eye diseases and additionally it can serve as a useful diagnostic test in numerous neurological and internal diseases. The test might also be used for monitoring purposes. Aim: The aim of the authors was to evaluate a digital central critical flicker-fusion frequency measuring device (IMEA ADR III) in 30 young, healthy Hungarian subjects. Method: After a general ophthalmological screening examination, monocular central critical flicker-fusion frequency was measured with four colours. Measurements were carried out on two separate days in three sessions under standardized conditions. Intrasession, intersession and intervisit variabilities, differences in central critical flicker-fusion frequency using the four colours and the effect of certain other influencing factors were determined. Results: There were no statistically significant differences between sessions in the mean and standard deviation of the measurement sets. The central critical flicker-fusion frequency threshold for red colour was significantly lower than for other colours, and the threshold for blue colour was significantly lower than for green. There were no significant differences regarding sex, age, iris colour, and smoking indicating that these factors did not influence the central critical flicker-fusion frequency threshold in these subjects. Conclusions: Measurement results with the device are reliable and reproducible in healthy, young population in separate sessions.

Keywords: critical, flicker, fusion, frequency, CFF, reproducibility

Angeli, O., Veres, D. S., Nagy, Z. Zs., Schneider, M. [Reproducibility of measurements using the IMEA ADR III critical flicker-fusion frequency measuring device]. Orv. Hetil., 2016, 157(27), 1084-1091.

(Beérkezett: 2016. március 21.; elfogadva: 2016. április 16.) 


\section{Rövidítések}

$\mathrm{AMD}=$ (age-related macular degeneration $)$ időskori maculadegeneráció; $\mathrm{CFF}=$ (central critical flicker-fusion frequency $)$ centrális kritikus fúziós frekvencia; $\mathrm{COV}=($ coefficient of variation) átlagos variációs együttható; $\mathrm{DR}=$ diabeteses retinopathia; ICC $=$ (intraclass correlation coefficient) összetartozási együttható; IQR = (interquartile range) interkvartilis távolság; Kendall $\mathrm{W}=$ Kendall-féle egyetértési együttható; LED = (lightemitting diode) fényt kibocsátó dióda; $\mathrm{REF}=$ referenciatartomány; SD = standard deviáció; $\mathrm{SEM}=$ (standard error of the mean) standard hiba; $\mathrm{SM}=$ sclerosis multiplex

A centrális kritikus fúziós frekvencia (central critical flicker-fusion frequency - CFF) mérés a látópályarendszer funkcionális vizsgálómódszerei között kiemelkedő jelentőséggel bír. A CFF-érték a látópályarendszer ingervezetési képességét határozza meg objektív számadatokkal. Ha a szemet fokozatosan növekvő frekvenciával különálló fényjelek érik, egy bizonyos határértéknél, a kritikus fúziós frekvenciánál a jelek egybeolvadnak, a szem folyamatos fényt lát.

Más eredményeket kapunk, ha a LED-fényt a foveára vagy a retina perifériájára fókuszáljuk [1]. A továbbiakban a centrális, vagyis a foveára fókuszált CFF tárgyalásával foglalkozunk kizárólagosan.

A CFF értékét a másodpercenkénti fényimpulzusok számával, a fényimpulzus frekvenciájával adjuk meg. Normálértéke $40 \mathrm{~Hz}$, azaz 40 fényimpulzus másodpercenként [2].

A teszt klinikai hasznossága abban áll, hogy segítségével egyszerúen és gyorsan képesek vagyunk számos betegség detektálására. Kiemelendő, hogy a CFF-mérés alkalmas lehet neurooftalmológiai betegségek szürésére, illetve sok esetben az addig ismeretlen neurológiai vagy belgyógyászati alapbetegségeket is felfedezhetjük, ami a szemészeti tünetek hátterében áll. A klinikumban ezenkívül kézzelfogható előnyöket nyújt, ugyanis a CFF-vizsgálat nemcsak a látópálya betegségeinek megállapításában fontos, hanem adott esetben a terápia hasznosságát, illetve a betegség progresszioját vagy regresszioját is tudjuk vele monitorozni.

A CFF-értékkel jellemezhetjük a retinocorticalis rendszert, a látóideg és a látópálya állapotát. A fenti struktúrákat érintő kórképekben (például neuritis retrobulbaris, papillitis, glaucoma okozta nervus opticus károsodás stb.) a CFF-küszöb csökken. Az életkor elörehaladtával szintén csökken a CFF-küszöb, körülbelül 40 éves korig $40 \mathrm{~Hz}$ a normálérték, ami megközelítőleg 50 éves kortól kismértékben, fokozatosan csökken [3].

A vizsgálat előnyei közé tartozik, hogy a technológiának és az eszköz felhasználóbarát kialakításának köszönhetően gyorsan kivitelezhető, betegágynál is elvégezhetó, és a sikeres vizsgálathoz a beteg minimális kooperációjára van csak szüikség.

A vizsgálat eredményét a fent említett betegségeken és az életkoron kívül azonban számos egyéb tényező is befolyásolja. Az eredményt módosító faktor lehet például a megvilágító fény ereje $[1]$, színe $[4,5]$, kitöltési tényezője [6] (a LED egy periódusra vonatkozó világítás időtartama). Továbbá módosul a CFF cataracta [7] vagy maculadegeneráció [4] jelenlétében, alkoholfogyasztás [8] és dohányzás [8] hatására, és nemtől függő́en [9] is. Az eredményt befolyásolja a háttérvilágítás [1], az írisz színe [10], illetve, hogy melyik napszakban [11] történik a mérés.

\section{Betegek és módszer}

A vizsgálatot a Helsinki Deklaráció etikai normáival összhangban végeztük. Minden résztvevő részletes felvilágosítást kapott és beleegyező nyilatkozatot írt alá. A vizsgálatot az Egészségügyi Tudományos Tanács Tudományos és Kutatásetikai Bizottsága (ETT TUKEB) szakhatósági állásfoglalása alapján az Egészségügyi Nyilvántartási és Képzési Központ engedélyezte.

A vizsgálatra való alkalmasság feltétele volt a betöltött 18. életév és a szemészeti betegségek hiánya, kivéve a fénytörési hibákat. Kizárási kritérium volt az ismert epilepsziás hajlam, a villogó fény esetleges rohamot kiváltó jellege miatt.

A vizsgálat során a magyar fejlesztésú, IMEA ADR III digitális CFF-mérő készüléket (Imea Ophthalmic Instruments, Eszteregnye, Magyarország) használtuk (1. ábra). Elsődleges célunk az eszközzel végzett mérések reprodukálhatóságának vizsgálata volt egészséges, kaukázusi populáción. Másodlagos célunk az egyéb befolyásoló faktorok tanulmányozása volt.

Az új fejlesztésű mérôkészülék előnye az eddig forgalomban lévő múszerekhez képest egyrészt az, hogy nemcsak zöld (hullámhossz: 523-525 nm) színnel, hanem kék (hullámhossz: 462-465 nm), vörös (hullámhossz: 625-635 nm) és fehér (a hullámhossz függ a beállított fényintenzitástól) natív LED-vizsgálófénnyel is múködik, ami lehetôvé teszi az egyes színeknél a küszöbértékek összehasonlítását. Több korábbi klinikai vizsgálatban is leírták, hogy bizonyos betegségeknél (például diabeteses retinopathia, sclerosis multiplex, idôskori maculadegeneráció) a különböző színeknél eltérő küszöbértékek mérhetók: így például diabeteses retinopathiában a kék, sclerosis multiplexben a vörös szín küszöbértéke alacsonyabb a többi szín küszöbértékénél.

A készülék továbbá rendelkezik egy környezeti fénymérővel, ami túl sok környezeti fénymennyiség esetén figyelmezteti a vizsgálót, hogy a környezeti fényhatások miatt a vizsgálat során torzulások állhatnak elő, amelyek téves eredményhez vezethetnek.

A LED-fénynek külön beállitható a kezdő frekvenciája, a fényereje és a kitöltési tényezője is. A készülék külső kialakítása is modern és felhasználóbarát, a nagyméretú forgatható vezérlőgomb érzékenysége szintén egyénileg beállítható, és lehetôvé teszi a nagy precizitású mérést.

A vizsgálatba összesen 30 egészséges, 18. életévét betöltött alany 30 szemét vontuk be ( 14 nő, 16 férfi; átlagéletkor: 23,3 év, minimum: 20 év, maximum: 42 év). 


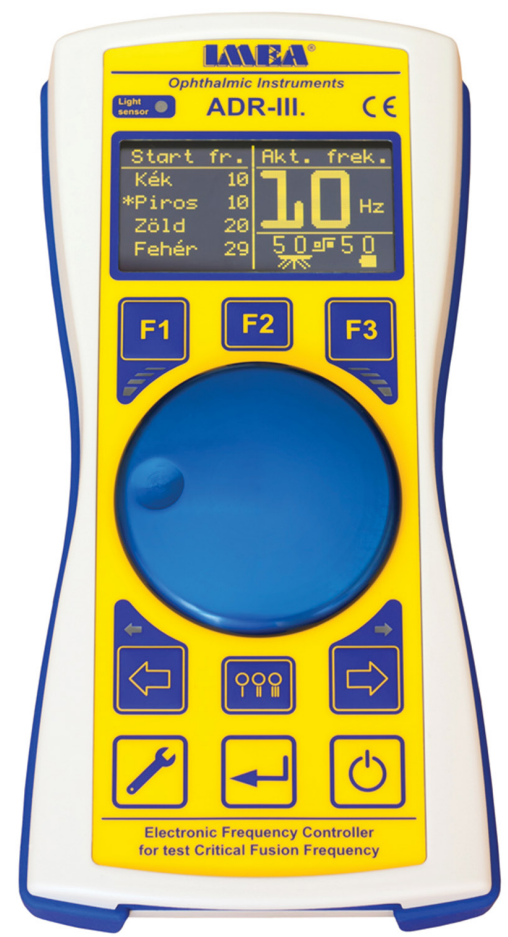

1. ábra

| Az új típusú, IMEA ADR III mérőkészülék

A vizsgálati alanyok többségének korrigált visusa 1,0 volt, 22 esetben kisfokú, 1 páciensnél nagyfokú myopia, illetve két páciensnél egyoldali tompalátás fordult elő.

A demográfiai adatok felvételét követően centrális retinán történő CFF-mérést, majd általános szemészeti szûróvizsgálatot (automata refraktometria, visusfelvétel, réslámpás vizsgálat, szemfenéki vizsgálat pupillatágítás nélkül) végeztünk. Minden résztvevő jobb szemét, a két tompalátó résztvevő esetében a nem amblyop szemet vontuk be a kiértékelésbe.

A CFF-mérés a gyári ajánlásnak megfelelően, mezopikus környezetben, standardizált fényviszonyok mellett történt. A tesztek számadatait két vizit alkalmával vettük fel, amelyek során a vizsgálathoz szükséges LED-fényt a páciens arcától $40 \mathrm{~cm}$-re helyeztük el. A LED fényerejét és kitöltési tényezőjét a gyári beállításon, azaz 50\%-on alkalmaztuk, a tekerőgomb érzékenysége 1-32-es skálán a gyári, 16-os értéken volt. Szintén gyári beállítású, 20-as kezdő frekvenciával kezdtük a mérést, és $2 \mathrm{~Hz} / \mathrm{s}$ sebességgel haladtunk a magasabb frekvenciák felé. A hagyományos CFF-mérési protokollt követve, a küszöböt két irányból történő méréssel közelítettük meg. A jelzett küszöbnél $5 \mathrm{~Hz}$-cel feljebb mentünk és onnan jöttünk ugyanolyan sebességgel visszafelé. A kisebb frekvenciák irányába történő mérés során a páciens ismét jelezte a CFF-küszöb helyét, és a két kapott érték alapján írtuk le a végleges eredményt. Egy mérési sorozaton belül a vizsgált szemen mind a négy színnel 5 mérést végeztünk.

Az első vizit alkalmával két vizsgálatot végeztünk 5 perc különbséggel, azaz két ülésben mértünk. A reprodukálhatóság vizsgálatára először kiszámoltuk az első ülés összes mérési sorozatán belüli (intrasession) variabi- litást, majd az 5 perccel későbbi második ülés és az első ülés közötti (intersession) variabilitást vizsgáltuk. A második vizit során egy héttel később, az első vizittel azonos napszakban már csak egy mérési sorozatot készítettünk (azaz egy ülésben mértünk), és az első vizit második ülésének eredményeihez viszonyítva néztük a reprodukálhatóságot (intervisit-variabilitás).

A mérési eredményeket statisztikailag feldolgoztuk, ennek során számítottuk ki a fenti variabilitásokat.

Vizsgáltuk továbbá azt is, hogy az egyes színek küszöbértékei között van-e a klinikai gyakorlat szempontjából releváns különbség, illetve számításokat végeztünk annak megállapítására is, hogy az életkor, a nem és a dohányzás hatással van-e a szórásra (SD), illetve a mediánra.

A statisztikai elemzésekhez az $\mathrm{R}$ 3.0.1-es verzióját ( $\mathrm{R}$ Foundation for Statistical Computing, Bécs, Ausztria), illetve a Friedman, Dunn post hoc teszthez a GraphPad Instat 3-as verzióját (Graphpad Software, La Jolla, CA, Amerikai Egyesült Államok) használtuk.

\section{Eredmények}

Az egyes páciensek összes ismételt mérésének mediánját alapul véve Spearman-korrelációt végeztünk az egyes színekre. Ennek eredményeként megállapítható volt, hogy a páciensek jobb és bal szemei jól korrelálnak egymással, értékeik eltérése kicsi (minden szín esetében p<0,0001, Spearman $\mathrm{R}>0,65$, lineáris, 0 tengelymetszetü modellben a meredekség eltérése 1 -tól $<0,015)$, így a továbbiakban csak a jobb szem eredményeit dolgoztuk fel részletesebben (2. ábra).

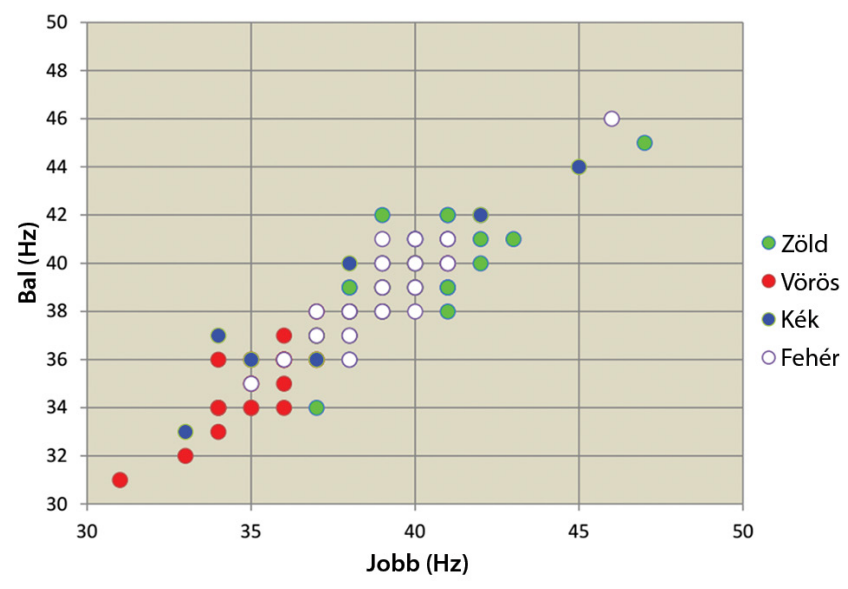

\begin{tabular}{l|l} 
2. ábra & A jobb és bal szem eredményeinek összehasonlítása az egyes szí-
\end{tabular} nekre nézve

$\mathrm{Az}$ intersession és az intervisit értékeit a megfelelő ülésekből számított mediánok adták. Így az intrasession esetében 5, az intersession és intervisit esetében 2-2 ismétlést kapunk.

Vizsgáltuk, hogy az ismétlések során van-e szignifikáns különbség a középértékekben és szórásokban. 
1. táblázat $\mid$ Az intrasession-variabilitás paraméterei COV, Kendall W és ICC együtthatókkal

\begin{tabular}{|c|c|c|c|c|c|c|c|c|c|c|c|c|}
\hline \multirow{2}{*}{$\begin{array}{l}\text { Intrasession- } \\
\text { variabilitás }\end{array}$} & \multicolumn{4}{|l|}{ Session 1} & \multicolumn{4}{|c|}{ Session 2} & \multicolumn{4}{|c|}{ Session 3} \\
\hline & Zöld & Vörös & Kék & Fehér & Zöld & Vörös & Kék & Fehér & Zöld & Vörös & Kék & Fehér \\
\hline $\operatorname{COV}(\%)$ & 1,92 & 1,42 & 1,49 & & & & & & & & & \\
\hline Kendall W & 0,87 & 0,94 & 0,88 & 0,92 & 0,87 & 0,93 & 0,92 & 0,87 & 0,75 & 0,89 & 0,87 & 0,90 \\
\hline ICC (konf.) & $\begin{array}{l}0,84 \\
(0,75-0,91)\end{array}$ & $\begin{array}{l}0,94 \\
(0,90-0,97)\end{array}$ & & & & & & & & & & \\
\hline
\end{tabular}

$\mathrm{COV}=($ coefficient of variation $)$ átlagos variációs együttható; $\mathrm{ICC}=$ (intraclass correlation coefficient) összetartozási együttható; Kendall W = Kendall-féle egyetértési együttható.

A középértékek összehasonlítását 2 ismétlés esetében Wilcoxon-féle előjeles rangpróbával, több ismétlés esetében Friedman-teszttel, Dunn post hoccal végeztük el. A szórásokat Levene-teszttel hasonlítottuk össze. A szignifikanciaszintet 5\%-nál határoztuk meg.

Vizsgálataink adataiból átlagos variációs együtthatót (coefficient of variation - COV), összetartozási együtthatót (osztályon belüli korreláció, intraclass correlation coefficient - ICC) és Kendall-féle egyetértési együtthatót (Kendall W) számítottunk, valamint a COV számításához minden egyes páciensnél kiszámítottuk az ismétlésekből kapott szórás és medián hányadosát, majd ezeket átlagoltuk. A Kendall W konkordanciavizsgálat minden esetben egyetértést mutatott $(\mathrm{p}<0,0001)$. Az ICC-értékeknél feltüntettük a 95\%-os konfidenciaintervallumot is. A Bland-Altman jellegú ábráknál, amelyek a zöld szín eredményeit mutatják, a minimális és maximális értékeket vettük, mint 2 ismétlési érték az intrasession esetében, és ezt az 5 ismétlés mediánjának függvényében tüntettük fel ebben az esetben. (Az ábrák elkészítése előtt meggyőződtünk róla, hogy a felhasználandó értékek szórása nem mutat korrelációt, „mintázatot” a középérték függvényében.)

\section{Intrasession-pariabilitás}

Megvizsgálva az első vizit első ülése összes mérési sorozatának középértékeit és szórásait, nem találtunk szignifikáns eltérést. A variabilitás paramétereit (COV, Kendall W, ICC) az 1. táblázatban tüntettük fel.

A Bland-Altman jellegú ábrákon az x tengelyen látható az adataink átlaga, az y tengelyen pedig az átlagtól való eltérés Hz-ben kifejezve. Az x tengely fölötti szaggatott vonal jelzi az átlagtól való átlagos eltérést, ami az intrasession-variabilitás esetén kevesebb mint $1 \mathrm{~Hz}$ volt.

A Bland-Altman-ábrákon az is látható, hogy a maximális különbség nem mutat korrelációt, mintázatot a mediánnal, illetve a pontok eloszlása a medián mentén nincs eltolva egyik irányba sem. A maximális különbségek legfeljebb két pont kivételével a különbségek referenciatartományán belül maradnak. Ezekből azt is látjuk továbbá, hogy a vizsgálati alanyok értékeinek szórásai is megegyezőnek tekinthetők (3.ábra).
2. táblázat $\mid \mathrm{Az}$ intersession-variabilitás paraméterei COV, Kendall W és ICC együtthatókkal

\begin{tabular}{l|l|l|l|l}
\hline $\begin{array}{l}\text { Intersession- } \\
\text { variabilitás }\end{array}$ & Zöld & Vörös & Kék & Fehér \\
\hline COV $(\%)$ & 2,31 & 2,04 & 2,14 & 2,05 \\
Kendall W & 0,85 & 0,91 & 0,82 & 0,87 \\
ICC (konf.) & 0,64 & 0,84 & 0,81 & 0,76 \\
& $(0,41-0,83)$ & $(0,69-0,92)$ & $(0,63-0,90)$ & $(0,56-0,88)$ \\
\hline
\end{tabular}

$\mathrm{COV}=($ coefficient of variation $)$ átlagos variációs együttható; ICC = (intraclass correlation coefficient) összetartozási együttható; Kendall $\mathrm{W}=$ Kendall-féle egyetértési együttható.

\section{Intersession-variabilitás}

Megvizsgálva az első vizit első és második ülése összes mérési sorozatának középértékeit és szórásait, nem találtunk szignifikáns eltérést. A variabilitás paramétereit (COV, Kendall W, ICC) a 2. táblázatban tüntettük fel.

A Bland-Altman-ábrák eredménye az intrasessioneredményekhez hasonló, természetében megegyezik. Láthatjuk, hogy a szaggatott vonal, azaz az átlagtól való átlagos eltérés itt még kisebb, majdnem egyenlő 0 -val. Ez alapján azt mondhatjuk, hogy a második ülés során mért eredmények megközelítőleg ugyanazok voltak, mint az 5 perccel korábbi, első ülés eredményei (4. ábra).

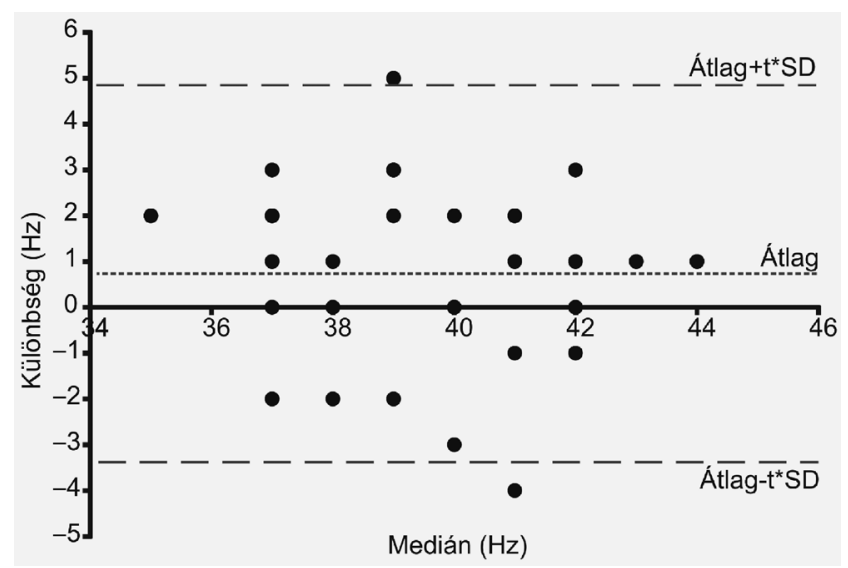

3. ábra | Bland-Altman-ábra intrasession-variabilitásra 


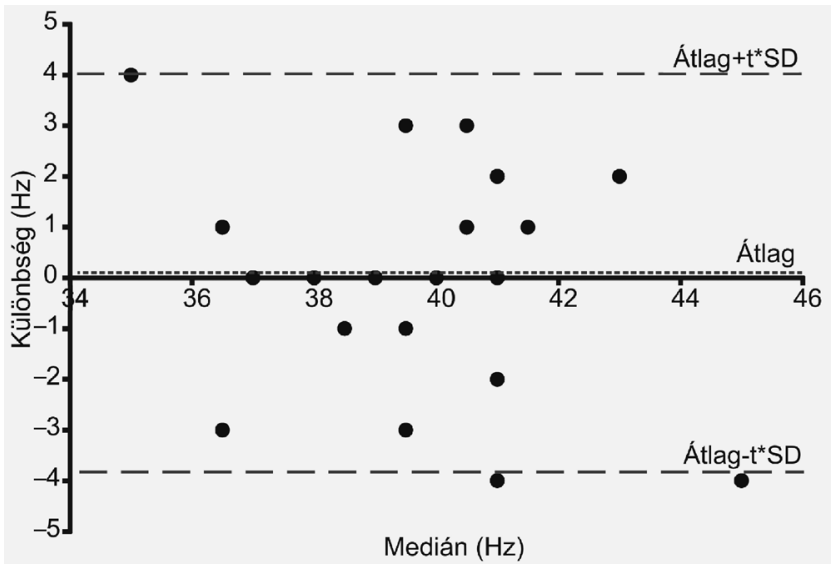

4. ábra

| Bland-Altman-ábra intersession-variabilitásra

\section{Intervisit-pariabilitás}

Megvizsgálva az első vizit második ülése és a második vizit összes mérési sorozatának középértékeit és szórásait, a vörös színt kivéve szignifikáns különbséget találtunk a középértékekben, azonban a szórásban a különbség nem volt szignifikáns. A vizsgálatunk alapján az látszik, hogy a több nappal későbbi viziten mért frekvenciák jelen vizsgálat során magasabbak voltak, azonban ennek mértéke csekély (1 Hz körüli), amely klinikai szempontból nem releváns, azonban befolyásolja a variabilitás paramétereit. A variabilitás paramétereit $(\mathrm{COV}$, Kendall $\mathrm{W}$, ICC) a 3. táblázatban tüntettük fel.

3. táblázat $\mid \mathrm{Az}$ intervisit-variabilitás paraméterei COV, Kendall W és ICC együtthatókkal

\begin{tabular}{l|l|l|l|l}
\hline $\begin{array}{l}\text { Intervisit- } \\
\text { variabilitás }\end{array}$ & Zöld & Vörös & Kék & Fehér \\
\hline COV (\%) & 2,89 & 2,65 & 2,45 & 2,95 \\
Kendall W & 0,78 & 0,81 & 0,82 & 0,75 \\
ICC (konf.) & 0,71 & 0,70 & 0,77 & 0,70 \\
& $(0,47-0,85)$ & $(0,45-0,84)$ & $(0,57-0,88)$ & $(0,47-0,85)$ \\
\hline
\end{tabular}

$\mathrm{COV}=($ coefficient of variation $)$ átlagos variációs együttható; ICC = (intraclass correlation coefficient) összetartozási együttható; Kendall $\mathrm{W}=$ Kendall-féle egyetértési együttható.

A Bland-Altman-ábrák eredménye az intrasessioneredményekhez hasonló, azzal az eltéréssel, hogy látszik az átlagos különbség 0-tól való eltérése (a későbbi időpontban közelítőleg $1 \mathrm{~Hz}$-cel magasabb a küszöbérték) (5. ábra).

\section{A szinek küszöbértékei}

A 4. táblázat az összesített mérésekből kapható, színeket jellemző értékeket mutatja be. Meghatároztuk az egyes páciensek összes ismételt mérésének mediánját, átlagát, interkvartilis távolságát (IQR) és szórását. Ezek átlagos

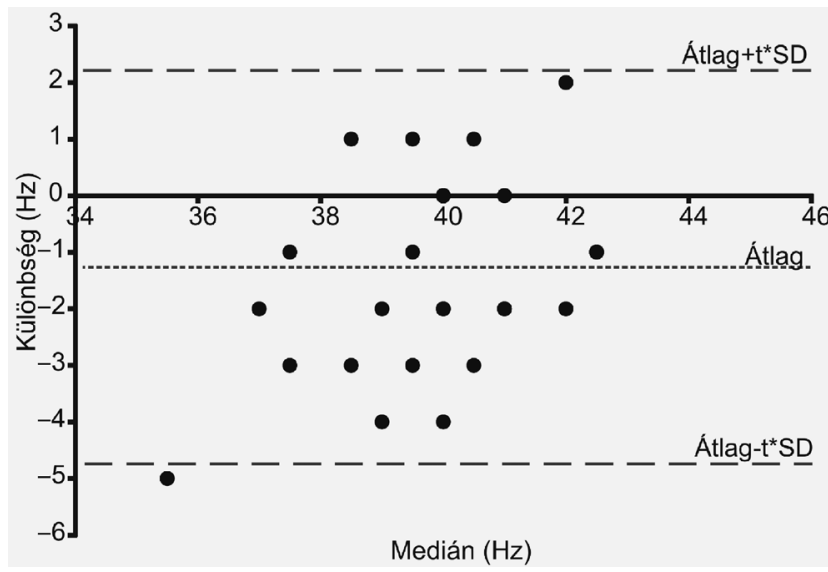

5. ábra | Bland-Altman-ábra intervisit-variabilitásra

értéke szerepel a 2. oszlopban, továbbá szórása a 3., standard hibája a 4., valamint referenciatartománya az 5 . oszlopban. (A referenciatartomány arra vonatkozik, hogy az adatok 95\%-a ebben az intervallumban található.)

A páciensek összes méréséből számított medián értékeket összehasonlítva a különböző színek esetében (Friedman-teszt, Dunn post hoc) szignifikánsan $(\mathrm{p}<0,01)$ kisebb küszöbértéket mutat a vörös szín mind-

4. táblázat |A színekre jellemző értékek összesített mérésekből

\begin{tabular}{lcccc}
\hline & Átlag & SD & SEM & REF \\
\hline Zöld & & & & \\
MED & 40,03 & 2,11 & 0,39 & $35,72-44,35$ \\
Átlag & 39,99 & 1,87 & 0,34 & $36,16-43,82$ \\
IQR & 1,9 & 1,01 & 0,18 & $-0,17-3,97$ \\
Szórás & 1,3 & 0,49 & 0,09 & $0,29-2,31$ \\
Vörös & & & & \\
MED & 35,73 & 1,93 & 0,35 & $31,79-39,68$ \\
Átlag & 35,77 & 1,99 & 0,36 & $31,7-39,84$ \\
IQR & 1,33 & 0,94 & 0,17 & $-0,59-3,26$ \\
Szórás & 1,02 & 0,39 & 0,07 & $0,22-1,82$ \\
Kék & & & & \\
MED & 38,63 & 2,22 & 0,41 & $34,09-43,17$ \\
Átlag & 38,79 & 2,1 & 0,38 & $34,49-43,08$ \\
IQR & 1,87 & 1,26 & 0,23 & $-0,71-4,44$ \\
Szórás & 1,18 & 0,54 & 0,1 & $0,09-2,27$ \\
Febér & & & & \\
MED & 39,23 & 1,98 & 0,36 & $35,19-43,28$ \\
Átlag & 39,3 & 1,95 & 0,36 & $35,32-43,28$ \\
IQR & 1,8 & 1,04 & 0,19 & $-0,32-3,92$ \\
Szórás & 1,19 & 0,46 & 0,08 & $0,25-2,13$ \\
\hline & & & & \\
\hline & & & & \\
\hline
\end{tabular}

$\mathrm{IQR}=$ (interquartile range) interkvartilis távolság; $\mathrm{MED}=$ medián; $\mathrm{REF}=$ referenciatartomány $\mathrm{SD}=$ standard deviáció $; \mathrm{SEM}=($ standard error of the mean) standard hiba. 


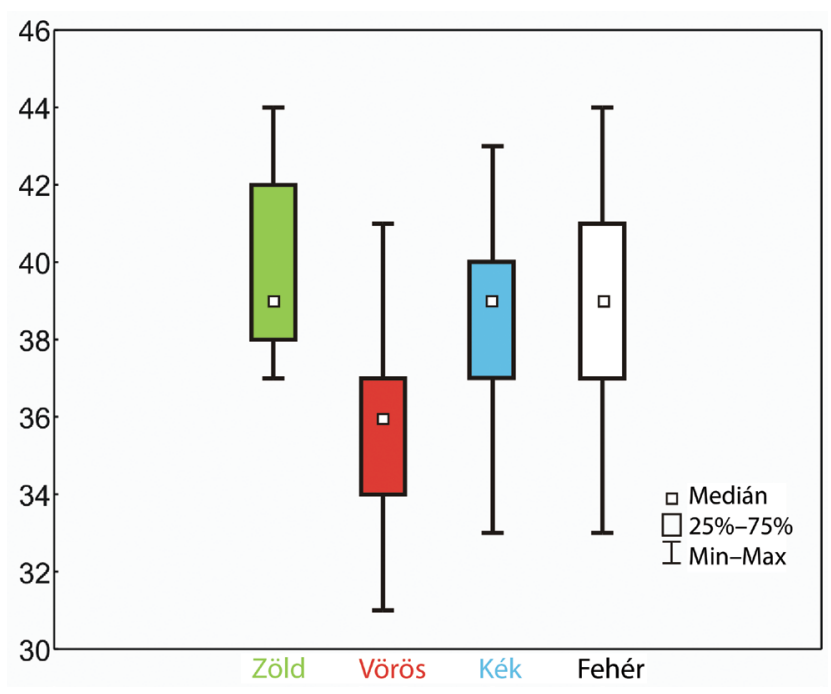

6. ábra $\mid \begin{aligned} & \text { Az egyes színek küszöbértékei közötti különbség a mediánok } \\ & \text { alapján }\end{aligned}$

egyik másik színhez képest, valamint a kék küszöbérték is szignifikánsan $(p<0,001)$ kisebb, mint a zöld. A zöld és fehér, illetve kék és fehér színek CFF-küszöbértékeit öszszehasonlítva, nem volt szignifikáns különbség ( $p>0,05)$.

A mediánokból szerkesztett összesített 6 . ábrán jól látható az egyes színek küszöbértékei közötti különbség.

\section{Dohányzás, életkor, nem, irisz szine}

A páciensek összes méréséből számított medián értékeket összehasonlítva (Mann-Whitney-féle U-tesztek) nem volt különbség a dohányzók és nemdohányzók küszöbértékei között.

A számítások alapján az sejthető, hogy az általunk vizsgált populációban az írisz színe nem volt hatással a küszöbértékekre, de ennek pontosabb elemzéséhez nagyobb vizsgálati elemszámra lenne szükség.

$\mathrm{Az}$ életkor és a nem szerepét egy generalizált lineáris modellben vizsgáltuk. A mediánokat, SD-ket (az egyes alanyok összes ismétléséból számított értékeit használva) megvizsgálva az egyes színekre azt mondhatjuk, hogy sem a dohányzás, sem a nem, sem az életkor nem korrelált a mediánnal, SD-vel.

Kiemelendő, hogy a vizsgálatok időben elhúzódó volta és némely páciens egyéni érzékenysége ellenére sem tapasztaltunk komolyabb kóros mellékhatást. A relatíve hosszadalmas és fárasztó vizsgálatok alatt a vizsgálati alanyok közül tizenöten jelezték, hogy szemük elfáradt, míg hárman szédülésre, émelygésre panaszkodtak. Ezek a panaszok valószínúleg arra vezethetók vissza, hogy a hagyományos CFF-vizsgálati idôt többszörösen meghaladtuk a mérések során.

\section{Megbeszélés}

Korábban számos tanulmány tárgyalta a centrális kritikus fúziós frekvencia küszöbértékének csökkenése és bizo- nyos betegségek, illetve befolyásoló faktorok összefüggéseit.

Egy 1981-es vizsgálatban glaucomás betegek súlyosabban érintett szemét hasonlították össze a kevésbé érintett szemükkel. A vizsgálat alapján a szerzők szignifikáns küszöbérték-csökkenést figyeltek meg a betegebb szem kapcsán. A vizsgált páciensek $80 \%$-ának volt jelentős centrális látáscsökkenése, és a betegség CFF-küszöbre gyakorolt hatása rendszerint csak a késői stádiumban manifesztálódott [12].

Egy másik tanulmány szerint az időskori maculadegenerációban is csökkent a CFF-küszöb, azonban a jó látóélességű non-exsudativ maculadegenerációban szenvedő páciensek és az egészségesek között nem volt lényeges eltérés. Ugyanebben a vizsgálatban színekkel is mértek küszöbértékeket, és azt tapasztalták, hogy non-exsudativ maculadegenerációban a vörös és a kék, míg exsudativ maculadegenerációbam a zöld színnél csökkent a küszöbérték a többi színhez képest [4].

Vizsgálták a CFF-küszöböt diabeteses retinopathiában és sclerosis multiplex okozta opticusneuritisben is. $\mathrm{Az}$ eredmények azt mutatták, hogy opticusneuritisben a vörös, diabeteses retinopathiában a kék szín CFF-küszöbértéke csökkent a kontrollcsoportokhoz képest. A szerzők konklúziója alapján összességében nagyobb mértékü csökkenést írtak le opticusneuritis esetén, mint diabeteses retinopathiában. Általánosságban megállapították azt is, hogy az életkor előrehaladtával a kék szín küszöbe egészségesekben is fokozatosan csökken [5].

Cataractás betegek CFF-vizsgálatának eredményei azt mutatták, hogy a kapott értékek nem függtek a betegség súlyossági fokától, hasonlóak voltak a kontrollcsoportban kapott értékekhez, és szinte semmit nem változtak az operációt követóen sem. Kiemelendő, hogy a tanulmány szerint a preoperatív vizsgálatok közül a CFF jósolta meg a legpontosabban a posztoperatív látóélességet az érett cataractás, egyéb szemészeti társbetegséggel (például időskori maculadegeneráció) is rendelkező betegeknél [7].

Egyes közlemények szerint nem mindegy, hogy milyen fényerősséggel és a retina melyik területére fókuszálva végezzük a méréseket. A megvilágítás erejének csökkentésével (a fénysugár és a környezet fényének egyaránt) a CFF-küszöbértékek egyöntetúen alacsonyabbak. Halvány megvilágításnál a CFF maximuma a foveánál van, és a periféria felé haladva fokozatosan csökken. Erősebb megvilágításnál viszont a CFF értéke a fovea felől a periféria felé haladva nő. Az erős háttérvilágításnál mért magasabb perifériás értékek nem azt jelentik, hogy a periféria általánosan érzékenyebb lenne a vibráló fényre, hanem azt az élettani jelenséget támasztják alá, hogy kétféle típusú receptív mező van a retinán, amelyek az alacsony vagy magasabb frekvenciatartománynak megfelelően eltérő érzékenységúek. Az egyik az alacsonyabb frekvenciatartományban érzékenyebb, és ez dominál a centrumban, míg a másik, a magasabb frekvenciatarto- 
mányban érzékenyebb típus, a periférián érzékel jobban $[1,12]$.

Egy 1982-es tanulmány a nemek közötti különbségeket vizsgálta, és egyértelmúen látszott, hogy a férfiaknak döntő többségben magasabb küszöbértékeik vannak [9].

Más tanulmányok szerint az írisz színe is hatással lehet a küszöbre, a kék szemúeknél mérték a legmagasabb értékeket, a barna szemúeknél a legalacsonyabbakat, míg a zöld szemúek a kettő közötti eredményeket adták [10].

Érdekes megfigyelés az is, hogy a CFF-küszöbnek egyénenként napszaki ingadozása van. Ez arra vezethetó vissza, hogy a cerebralis és a retinalis vérátáramlás a különböző napszakokban eltérő intenzitású lehet, ennek megfelelően az érzékelés is változik [11].

Tíz egészséges egyetemista férfin vizsgálták az egyik szem letakarásának CFF-küszöbre gyakorolt utóhatását a másik, szabadon maradt szemre nézve is. A szabadon maradt szemen CFF-küszöböt mértek a másik szem letakarása előtt, majd a letakarást követő 3 és 6 óra elteltével. A vizsgálatból az derült ki, hogy a szabadon maradt szem CFF-értéke a másik szem letakarásától számított 6 óra elteltével csökkent, majd a másik szem szabaddá tételétől számított 18 óra elteltével érte el újra a normálértéket [13].

Korábbi vizsgálatok kimutatták, hogy a CFF-küszöb közvetlenül egy cigaretta elszívása után nő, és közepes dózisú alkohol elfogyasztása után csökken. Emiatt a CFF-vizsgálatot régóta használják különböző élvezeti szerek/drogok hatásának mérésére, illetve az alkoholtolerancia mérésére is. A dohány nikotintartalma azonnal CFF-emelkedést okoz, ami körülbelül 5 perccel a dohányzás után elmúlik. Az alkohol bifázisos hatásának megfelelően bizonyos véralkoholszint alatt a CFF nő, magasabb koncentrációnál szignifikánsan csökken. Nikotin és alkohol egyidejű alkalmazásakor azonban elméletileg nem változik a küszöb, a két szer kiegyensúlyozza egymás hatását [8].

A fentiekből is egyértelmúen láthatjuk, hogy a CFFértéket számos tényező befolyásolja. Függ az eredmény a megvilágító fény hullámhosszától, a fénysugár átméröjétől, a szem adaptációjától és a vizsgálati alany éberségi állapotától is. A fénysugár a megfigyelőnek a készülék bekapcsolásakor az elsó pillanatban világosabbnak tűnik (Broca-Sulzer-hatás) [6]. Ha gyors ütemben ki-be kapcsoljuk a fényt, a fényintenzitás látszólagos növekedése és a villogás sebessége a kapcsolgatás sebességétől függ. Tehát egy átmeneti, látszólagos fényerősödés tapasztalható rövid ideig tartó felvillanáskor. Ez a vizsgálat kivitelezése szempontjából azért fontos, mert ezzel a mechanizmussal a „duty cycle”, azaz a kitöltési tényező változtatása akár 10-20\%-ban módosíthatja az eredményt, így ennek a paraméternek átállítása csak tapasztalt vizsgálóknak ajánlott, és főleg olyan esetekben alkalmazzák, amikor a vizsgálati eredmény nem egyértelmú.
Jelen tanulmányunkban néhány fent említett publikációhoz hasonlóan, a reprodukálhatósági vizsgálat mellett vizsgáltuk az egészséges páciensek CFF-küszöbe közötti különbséget is, az életkor, a nem, az írisz színe és a dohányzás vonatkozásában.

Szinte teljesen homogén, fiatal populációt vizsgáltunk, így az életkor előrehaladtával csökkenő CFF-küszöb nem volt kimutatható és nem befolyásolta a vizsgálat eredményeit. Nem találtunk különbséget a nemek között és a különböző íriszszínek között sem a CFF-küszöböknél. Ahogy eredményeinkben részleteztük, a számításokból arra lehet következtetni, hogy a fenti paraméterek reális összehasonlítására nagyobb elemszámú populációra lenne szükség.

Tanulmányunkban a dohányzás hatását általánosságban vizsgáltuk a CFF-küszöbre, ez a hatás a jelen vizsgálatban nem igazolódott. Ez valószínúleg azzal magyarázható, hogy az általunk vizsgált egyének átlagosan sokkal kevesebbet dohányoztak, mint a korábban említett tanulmány vizsgálati alanyai - összesesn 7 dohányzó alanyunk volt a 30-ból.

A klinikai vizsgálat megkezdése előtt felmerült a kérdés, hogy végezzünk-e színtesztet a vizsgálati alanyoknál. Arra a következtetésre jutottunk, hogy a színteszt nem szükséges, a következő okok miatt:

1. Ha az alany látja és meg tudja nevezni a színt, akkor a vibrálás frekvenciájának érzékelése szempontjából irreleváns, hogy színtévesztő (anomal) vagy nem.

2. Ha az adott hullámhosszra az alany teljesen anop (például protanop $=$ nem látja a vöröset), akkor nem fogja érzékelni a LED-fényt, ennélfogva nem lesz felvehető a CFF sem, és ez a vizsgálatkor rögtön ki is derül. A színteszt elvetésének további indoka volt, hogy alkalmazásával - és így az esetleges színtévesztók kizárásával korlátoztuk volna az eszköz használhatóságát. Vizsgálatunkban minden alanyunknál sikeresen el tudtuk végezni az összes mérést.

\section{Következtetés}

Az elvégzett vizsgálatok tapasztalatai és a statisztikai számítások alapján a múszer megbízhatóan, pontosan mér, az eredmények jól reprodukálhatóak. Így összességében kijelenthetjük, hogy a készülék alkalmas a mindennapi használatra a klinikai gyakorlatban, és újításai további kutatási célokra fordíthatók.

Anyagi támogatás: A közlemény megírása anyagi támogatásban nem részesült.

Szerzői munkamegosztás: A. O.: Beteg-interakció, CFFvizsgálatok, irodalomkutatás, a kézirat megírása, végleges változatának elfogadása. V. D. S.: Statisztikai elemzés. S. M.: Vizsgálattervezés, beteg-interakció, sze- 
mészeti vizsgálatok, a kézirat revíziója, végleges változatának elfogadása. N. Z. Zs.: A kézirat revíziója, végleges változatának elfogadása. A cikk végleges változatát valamennyi szerző elolvasta és jóváhagyta.

Érdekeltségek: A szerzőknek nincsenek érdekeltségeik.

\section{Köszönetnyilvánítás}

A CFF-mérő készüléket az Árgus Kft. bocsátotta rendelkezésünkre.

\section{Irodalom}

[1] Hartmann, E., Lachenmayr, B., Brettel, H.: The peripheral critical flicker frequency. Vision Res., 1979, 19(9), 1019-1023.

[2] Süveges, I. (ed.): Ophthalmology. [Szemészet.] Medicina Könyvkiadó, Budapest, 2015. [Hungarian]

[3] Misiak, H.: The decrease of critical flicker frequency with age. Science, 1951, 113(2941), 551-552.

[4] Maier, M., Groneberg, T., Specht, H., et al.: Critical flicker-fusion frequency in age-related macular degeneration. Graefes Arch. Clin. Exp. Ophthalmol., 2010, 248(3), 409-413.

[5] Gregori, B., Papazachariadis, O., Farruggia, A., et al.: A differential color flicker test for detecting acquired color vision impairment in multiple sclerosis and diabetic retinopathy. J. Neurol. Sci., 2011, 300(1-2), 130-134.
[6] Baatz, H., Raak, P., de Ortueta, D., et al.: Practical significance of critical fusion frequency (CFF). Chronological resolution of the visual system in differential diagnosis. Ophthalmologe, 2010, 107(8), 715-719.

[7] Del Romo, G. B., Douthwaite, W. A., Elliott, D. B.: Critical flicker frequency as a potential vision technique in the presence of cataracts. Invest. Ophthalmol. Vis. Sci., 2005, 46(3), 1107-1112.

[8] Leigh, G.: The combined effects of alcohol consumption and cigarette smoking on critical flicker frequency. Addict. Behav., $1982,7(3), 251-259$.

[9] Ginsburg, N., Jurenovskis, M., Jamieson, J.: Sex differences in critical flicker frequency. Percept. Mot. Skills, 1982, 54(3 Pt 2), 1079-1082.

[10] Smith, J. M., Misiak, H.: The effect of iris color on critical flicker frequency (CFF). J. Gen. Psychol., 1973, 89(1st Half), 91-95.

[11] Walsh, J. F., Misiak, H.: Diurnal variation of critical flicker frequency. J. Gen. Psychol., 1966, 75(1st Half), 167-175.

[12] Tyler, C. W.: Specific deficits of flicker sensitivity in glaucoma and ocular hypertension. Invest. Ophthalmol. Vis. Sci., 1981, 20(2), 204-212.

[13] Zubek, J. P., Harper, D. W.: After effects of short-term monocular deprivation on critical flicker frequency of the non-occluded eye. Percept. Mot. Skills, 1976, 43(1), 123-126.

(Schneider Miklós dr., Budapest, Mária u. 39., 1085 e-mail: schneider.miklos@med.semmelweis-univ.hu)

\section{A Magyar Személyre Szabott Medicina Társaság VII. kongresszusa}

\section{A személyre szabott orvoslás hatása a jövő egészségügyére}

A Magyar Személyre Szabott Medicina Társaság életre hívásával az egészségipar, kutatás-fejlesztés és orvoslás terén müködő szereplők kötelezettséget vállaltak arra, hogy munkájukkal hozzájáruljanak ahhoz, hogy a hazai egészségügy és annak müködési elvei terén az elkövetkezendő években jelentős változások mehessenek végbe. A Személyre Szabott Orvoslás (SZSZO) paradigmaváltást jelent a gyógyításban, egészség-gazdaságban, transzlációs medicinában. Ennek szellemében kerül sor hetedik kongresszusunkra, melynek elöadásai $A$ személyre szabott orvoslás hatása a jövő egészségügyére témára összpontosulnak.

\section{A konferencia időpontja: 2016. augusztus 26-27. \\ A konferencia helyszíne: Abacus Hotel, Herceghalom}

A konferencia pontszerző tanfolyamnak minősül, mind a szakorvosok, mind a PhD hallgatók számára:

OFTEX pontértéke: 32

GYOFTEX pontértéke: 32

A kongresszussal kapcsolatos egyéb információk, program, jelentkezési lap és részvételi dij az MSzMT honlapján (www.mszmt.hu) olvashatók.

Regisztrációs határidő: $\quad$ 2016. július 31 .

Kontakt: Polyák Krisztina - telefon: (06-20) 403-4955

Zeitlerné Kozma Zsuzsanna - telefon: (06-20) 414-9646

Szeretettel várjuk jelentkezését!

Dr. Németh György elnök 